\title{
1 Adapting futures scenarios to study 2 UK household energy demand
}

4 Author 1

5 - Miquel Banchs-Piqué

6 - School of Civil Engineering and Surveying, University of Portsmouth, Portsmouth, UK

7 - ORCID: 0000-0002-9022-2453

8 Author 2

9 - Dr. David J Hutchinson

10 - Faculty of Technology, University of Portsmouth, Portsmouth, UK

11 - ORCID: 0000-0002-0023-4689

12 Author 3

13 - Prof. Victor Becerra

14 - School of Engineering, University of Portsmouth, Portsmouth, UK

15 - ORCID: 0000-0002-3790-4236

16 Author 4

17 - Prof. Mark Gaterell

18 - School of Civil Engineering and Surveying, University of Portsmouth, Portsmouth, UK

- ORCID: 0000-0002-0504-4841

miquel.banchs-pique@port.ac.uk

\section{School of Civil Engineering \& Surveying, Portsmouth University}

24

Portland Building, Portland Street, Portsmouth (UK), PO1 3AH

25

+442392842428 


\section{Abstract}

30 Greenhouse gas emissions originating from the built environment play a significant role toward 31 climate change. Carefully planning the future of the building sector is key to mitigating these 32 emissions. Addressing this problem using a predictive approach may miss possible futures we 33 cannot anticipate. Using explorative scenarios to perform futures analysis helps widen the range 34 of futures taken into account, which minimises this risk. Tools which use scenarios to help study 35 the resilience of sustainable solutions for UK urban environment are already available. However, 36 they do not facilitate in-depth analysis of future household energy demand. This paper considers 37 how one such tool, 'Designing Resilient Cities' (DRC), could be modified appropriately. It includes: 38 (1) a series of indicators representing factors affecting the energy demand in dwellings, and (2) 39 their characteristics for each scenario to complement the narratives in DRC. As a case study to 40 validate these additions, the resilience of a recommendation to decrease domestic electricity 41 consumption is evaluated.

\section{Keywords}

45 Sustainability, Energy conservation, Environment

\section{List of acronyms}

49 GSG Global Scenarios Group (Tellus Institute)

50 DRC Designing Resilient Cities (tool to perform futures analysis)

51 UF Urban Futures (project which developed DRC)

$52 \quad$ NSP New Sustainability Paradigm (scenario)

$53 \quad P R \quad$ Policy Reform (scenario)

$54 \quad$ MF Market Forces (scenario)

55 FW Fortress World (scenario)

56 
60 Although we live in a world where post-truth intoxicates the beliefs of millions of people worldwide, there is scientific consensus on human-made climate change driven by greenhouse gases (Cook et al., 2016). Climate change is one of the Stockholm Resilience Centre's boundaries defining a safe operating space for humanity which we have already violated (Rockström et al., 2009). In order to mitigate this threat, most countries are setting targets to reduce their carbon dioxide emissions. In the case of the UK, in 2008 the Government's Climate Change Bill set a legally binding target of a $80 \%$ reduction in carbon dioxide emissions by 2050 compared to 1990 levels (DEFRA, 2008), and it recognises that the built environment plays a crucial role in achieving this target (Department of Energy and Climate Change, 2009).

69

Under business as usual, energy demand in the global building sector is expected to increase by $50 \%$ by 2050 (IEA, 2013). It has been estimated that to achieve the global goal of limiting the temperature rise to $2{ }^{\circ} \mathrm{C}$, the building sector has to reduce its carbon dioxide emissions by $77 \%$ compared to the 2013 baseline (IEA, 2013). Carefully planning the future of the built environment —as well as its energy supply technologies and networks - is key in this effort, as we need to ensure resilient and flexible solutions that continue to perform effectively in the future.

The future is, however, uncertain. Solutions which seem very appropriate today may not be useful in a matter of few years if this uncertainty is not taken into account during their design phase. To not do so would mean wasting resources and effort in what would soon become stranded assets. Present research on sustainability faces this problem principally by utilising a predictive approach -i.e. based on current and historical trends and predictions. This is perfectly valid, however, it does not account for futures we cannot anticipate (Rogers et al., 2012).

84 Scenario analysis can help in this regard as it facilitates widening the range of futures considered. So far, scenario analysis has been used mainly to study the consequences of global level interventions, long-term evolution of different systems, and to inform polices (Boyko et al., 2012). However, it is not extensively used to study the performance of specific interventions, or to evaluate the effects that 
different futures could have on a specific system. In particular, scenario analysis could be used to study the development of domestic energy demand, and the performance of interventions aimed at decreasing it.

In the future scenarios literature, there exist different types of scenarios, tools and methods designed to help perform futures analysis in a wide range of contexts. One tool which is especially suited to study the performance of sustainable interventions in the urban environment is 'Designing Resilient Cities' (DRC) (Lombardi et al., 2012), with their 'Urban Futures Method' (Rogers et al., 2012). This tool was developed by a project called 'Urban Futures' (UF), which published it in 2012 in parallel to a special issue of this same journal. That issue was dedicated to the use of future scenarios to evaluate the resilience of sustainable solutions in the urban environment in UK (Rogers, 2012).

UF used as the basis for their scenarios those developed by the Global Scenarios Group (GSG), a project from the Tellus Institute. These scenarios are integrated —considering major economic, social, cultural, institutional, technological and environmental questions at the same time- and disaggregated by regions and sectors; and they convey this information in various points in the future until the year 2100 (Raskin, Electris and Rosen, 2010). These are explorative scenarios which cover a broad range of possible directions in which the future could unfold, and can be used to formulate 'what if' questions (Rogers et al., 2012). GSG took special care to make the scenarios a logical and plausible evolution from the world today and internally consistent (Gallopin et al., 1997). UF adapted four of these scenarios to UK cities in 2050 and developed DRC to help to evaluate the resilience of sustainable urban interventions (Boyko et al., 2012; Lombardi et al., 2012).

The four scenarios developed by UF are internally-consistent adaptations to the UK urban environment of the following GSG scenarios:

- New Sustainability Paradigm (NSP) - engaged society with a shared vision for sustainability and quality of life,

- Policy Reform (PR) - coordinated action from governments for sustainability and against poverty,

- Market Forces (MF) - reliance on the self-correcting logic of competitive markets, 
- Fortress World (FW) - alliances of the powerful to protect their interests, security first; poor majority live outside the fortress (ratio 35:65).

120 These four scenarios extend to the extremes of plausibility and are sufficiently distinct to cover a wide range of possible futures (Hunt et al., 2012a). The names of the scenarios give a good idea of their characteristics. However, if further description is sought, brief general narratives can be found in the following literature: for the general GSG scenarios see Hunt et al. (2012b), for a version representative of OECD countries see Rogers et al. (2012), and for the UK urban version developed by UF see Boyko et al. (2012) or Lombardi et al. (2012).

127 The 'Urban Futures Method' "aims to broaden the way we think about the form, function, and context of urban development and regeneration by focussing on the likely long-term performance of today's urban design solutions, and their associated vulnerabilities" (Lombardi et al., 2012). This aim partly covers the study of the energy demand of UK's residential sector. However, to do an in-depth analysis of this topic, the tool has to be adapted. Fortunately, the scenarios used in DRC are designed in a way that new indicators and characteristics can be added to them, as well as new scenarios incorporated to the tool (Boyko et al., 2012).

135 And so, the objective of this paper is to adapt the scenarios from DRC to the study of the energy demand of UK's residential sector. This is done by adding a set of indicators related to household energy demand or its causes, and developing their characteristics for each scenario, which increases the detail of information the scenarios provide in this domain. A short case study is also presented here to demonstrate the use of these additions.

\subsection{Future scenarios}

144 One very important characteristic of scenarios is that they do not intend to predict the future. What 145 scenarios do, is to map a plausibility space in order to explore or study it (Schwartz, 1991; Foresight 146 Horizon Scanning Centre and Government Office for Science, 2009; Boyko et al., 2012; Rogers et al., 
147 2012). Therefore, scenarios are tools to help thinking about the future in a structured way and based

148 on a set of assumptions which are previously defined.

150 There exist many types of scenarios with different features depending on the use to which they are put.

151 Some, model possible outcomes and consequences from current actions and may not need any narrative - e.g., the different emissions scenarios that IPCC developed for each of their storylines

153 (IPCC, 2000). The scenarios discussed here, in contrast, are defined by narratives and explore distinct plausible socio-economic futures which could arise from the present.

156 The use of these kinds of scenarios provides information on the possible evolution of any subject of 157 study in a range of futures. This can be valuable for many purposes. In particular, it can provide information on the performance of any proposed intervention in different futures, thus helping to improve

159 its resilience - i.e. its effectiveness in all the scenarios - or, at least, informing of its weaknesses 160 (Boyko et al., 2012; Lombardi et al., 2012; Rogers et al., 2012).

The narrative of the scenarios in DRC comprises a short general narrative and the characteristics of a set of indicators. The general narrative describes briefly and precisely the main aspects of the scenario, and the characteristics of the indicators, its details. The indicators are variables that represent attributes of the system -e.g. the size of the population in the scenario- and they can represent any aspect(s) of interest. They have to be accurately defined, with a unit of measurement, and normally their value in a reference scenario or some kind of benchmark. The characteristics of an indicator quantify or qualify, with short statements, its performance under each scenario, normally in relation to the reference (Boyko et al., 2012). For ease of use, the trend in relation to the reference is also portrayed with an arrow. See Figure 1 for a graphical depiction of the composition of a DRC scenario narrative. 


\section{Scenario narrative}

General

narrative

Attribute(s) $1 \longrightarrow$ Indicator $1 \quad$ Characteristics 1

Attribute(s) $2 \longrightarrow$ Indicator $2 \quad$ Characteristics 2

173

174

175

176

177

178

179

180

181

182

183

184

185

186

187

Figure 1. DRC scenario narrative composition. The narrative of each scenario comprises a brief general narrative describing the main aspects of the scenario and the characteristics describing the performance of a set of indicators in the scenario. These indicators are variables representing one or more attributes of the system.

\section{Attribute(s) $\mathrm{n} \longrightarrow$ Indicator $\mathrm{n} \quad$ Characteristics $\mathrm{n}$}

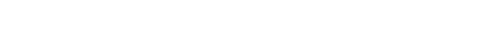

Note that all scenarios are defined by the same set of indicators; the differences in the characteristics of these indicators between the scenarios are what, in conjunction with the general narratives, portray the differences between the scenarios. In order for the scenarios to provide coherent information, it is important that the characteristics of the indicators are internally consistent and that they are based on the relevant literature. Both, GSG and UF have put great effort in doing so (GTI, 2018; Gallopin et al., 1997; Raskin et al., 1998, 2002; Rogers et al., 2012). Otherwise, the characteristics of one indicator could be contradictory with those of another indicator or with the general narrative of the scenario.

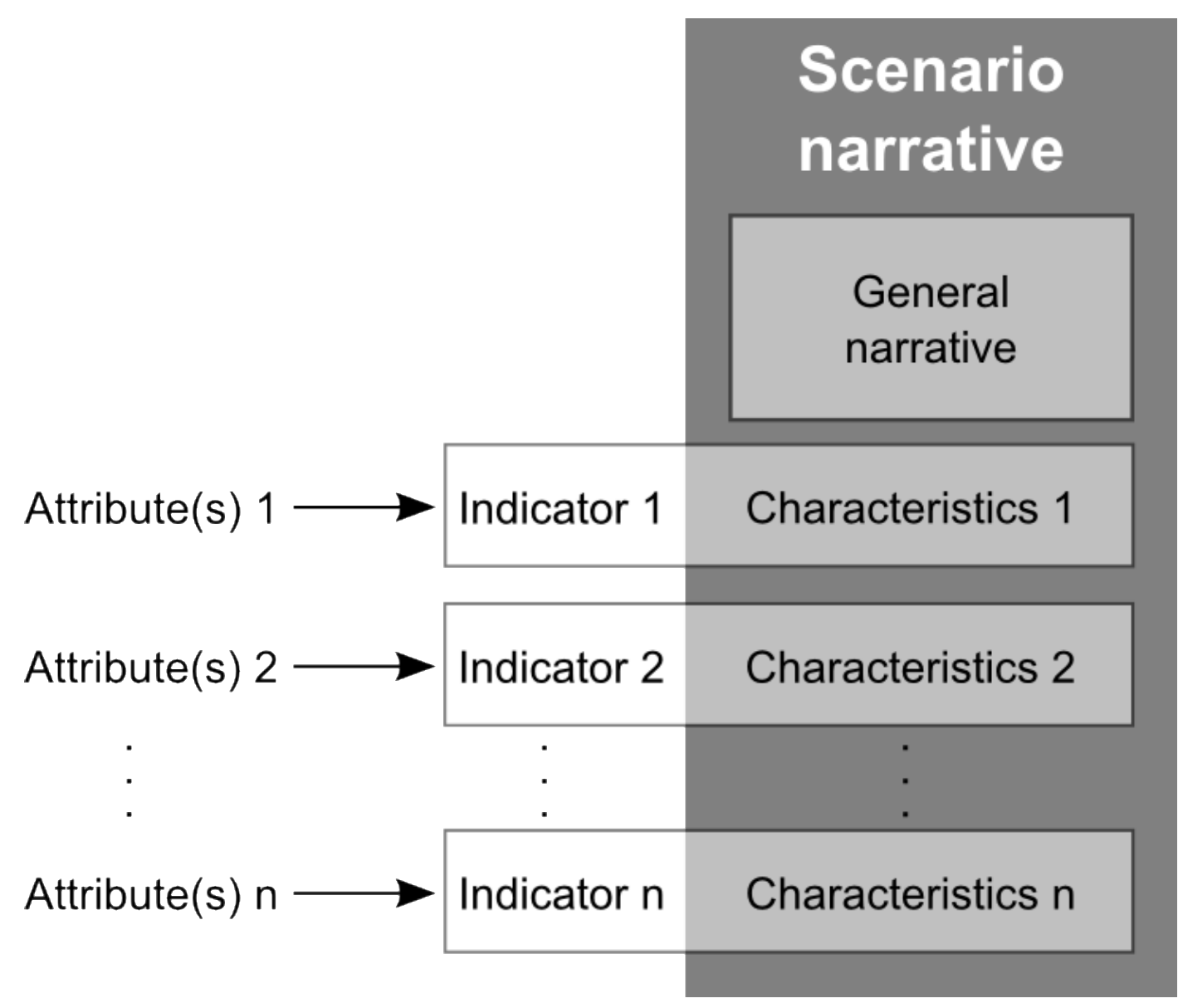


Many highly interrelated factors play a role in determining the energy any given building will consume to establish and maintain a comfortable temperature, air quality and light levels (Thomas, 2006).

Larger dwellings tend to use more energy, but still with extensive differences between similar dwellings

194 (Wright, 2008). When trying to understand the key factors which explain the energy consumed in buildings, building factors alone are shown to explain at least $39 \%$ of the variability of energy use in buildings (Sonderegger, 1978; Guerra Santin, Itard and Visscher, 2009; Huebner et al., 2015a). However, Huebner et al. (2015a) shows that when taking into account other factors (such as socioeconomic factors - which by themselves explain $24 \%$ of variability) in a combined model, they can only explain $44 \%$ of variability.

200

201 This leaves more than $50 \%$ of the variability in domestic energy consumption unexplained (Huebner et al., 2015b). Indeed, a crucial factor in the energy households consume is the behaviour of the inhabitants of the dwellings (Firth et al., 2008; Perry and Bessant, 2014). Heating (gas) consumption is mainly influenced by occupancy of the property (who, how long...) and temperature management (Fell and King, 2012; Weber et al., 2017), with ventilation behaviour having a major impact too (Weber et al., 2017). Variables influenced by people have the strongest predictive power to explain English household non-heating electricity consumption (Huebner et al., 2016). This consumption is determined mainly by the type and number of electrical appliances, and the use the occupants make of them (Firth et al., 2008; Huebner et al., 2016). However, studies repeatedly show that it is very difficult to change the energy behaviour of a large group of users (Perry and Bessant, 2014).

211

212 The energy used for space heating is, by far, the largest slice of the energy used in UK households.

213 Together with water heating - the second largest slice — they accounted for around $80 \%$ of the energy 214 used in UK households in 2011 (Palmer and Cooper, 2013). The energy source used for heating by the vast majority of homes in the UK (more than $80 \%$ ) is gas. Most of the non-gas energy used for heating,

216 as well as virtually all the energy used for non-heating related purposes in UK households is electricity.

217 Therefore, these two sources of energy account for almost all the energy used in UK households. 
219 Better building standards and new regulations mandating and promoting them promise to decrease the 220 energy consumed in new buildings. However, there is a large stock of already constructed residences which need to be addressed; it is estimated that two-thirds of the dwellings likely to be in use in UK in 2222050 were already constructed in 2005 (Boardman et al., 2005). Therefore, significantly reducing the energy consumption of domestic buildings means the existing stock needs to be refurbished. It is calculated that with only the insulation of lofts and cavity walls, the consumption of fuel for space heating in England could be reduced by between $10 \%$ and $17 \%$ (Hong et al., 2006).

Some recommendations to decrease household electricity demand arising from one of the biggest measurement campaigns ever made, in Sweden, are to limit the power consumption of appliances on standby to $0.5 \mathrm{~W}$, encourage cutting the electrical supply of the appliances instead of leaving them in standby mode, and accelerating stricter consumption norms to make class $A$ appliances become the standard (Zimmermann, 2009).

232

A futures analysis of the factors affecting the energy demand in households would identify a range of distinct plausible paths this demand could take in the future, thus reducing the uncertainty faced when designing interventions, plans or regulations affecting it.

2 Developing domestic energy demand indicators

240 This section describes the methods used to define the indicators that needed to be developed to study

241 the energy demand of the domestic sector in the context of the tool 'Designing Resilient Cities' (DRC)

242 (Lombardi et al., 2012), as well as how their characteristics for the four future scenarios were developed.

244 The system attributes that the indicators developed here represent are the main factors affecting the energy demand of households. These factors can be found, for example, in Bhattacharjee and Reichard 246 (2011), Huebner et al. (2015a), Jones and Lomas, (2015), Jones, Fuertes and Lomas (2015). These sources were used to rank factors in order of importance. Factors which overlapped significantly with 
248 each other and with those from DRC were synthesized to a single indicator (e.g. the factors 'number of

249 rooms', 'number of bedrooms' and 'number of floors' were blended into 'total floor area'); sets of factors

250 conveying redundant or overlapping information were grouped to form a smaller number of indicators

251 when this did not imply significant loss of information (e.g. three factors grouped to create two

252 indicators); and factors with smaller or no clear impact in the energy demand of households, or without

253 reliable information to characterise an indicator, were discarded (e.g. the infancy of domestic energy

254 storage technologies would have made the analysis of their future evolution very uncertain). Then a

255 justification and/or definition was written for each indicator along with the question the indicator answers.

256

257 Before developing the characteristics of an indicator, the current value of the indicator was found, and

258 the factors on which the indicator depends were listed. Then, the characteristics of the indicators which

259 give information about these factors (both, from DRC and from the list of indicators developed for this

260 analysis) were put together. If needed, missing information about any of the factors was added from the

261 literature related to the GSG (GSG, Tellus Institute), as well as the characteristics of other related

262 indicators and/or context information extracted from the general narrative of the scenarios. See the

263 indicators and other information used to derive the characteristics of each new indicator in Table 1. With

264 this information the narrative for the characteristics of the new indicators was derived for each scenario,

265 and their general trend in relation to the baseline symbolized by an arrow. Figure 2 depicts an analogy

266 between the process to derive the characteristics of a new indicator for one scenario and a sum. As

267 many indicators depend on each other, iterations of the whole process helped improve the final result.

268 Generally, for clarity, a short review of the information put together for each scenario was written (see

269 Table A1 - 'Review and context' in Appendix). In case of isolated discrepancies between the

270 characteristics of the indicators used to derive new indicators and the general narrative of the scenarios,

271 the general narrative has been used. Find a brief justification on the choice of indicators in the

272 Supplementary information S1.

273

274 
276 Table 1. Indicators and other information used to derive each of the new indicator's characteristics. References: E[R] report (Greenpeace, 2015), General narratives from DRC (Lombardi et al., 2012), General GSG narratives (D. V. L. L. Hunt, Lombardi, Atkinson, Barber, et al., 2012), Technical document (Electris et al., 2009), Table generator tool (Tellus Institute, no date).

\begin{tabular}{|c|c|c|c|}
\hline Indicator & Indicators from 'Designing resilient cities' & Indicators developed in this work & Other factors and sources \\
\hline $\begin{array}{l}\text { Adoption of domestic (or } \\
\text { community) micro-generation }\end{array}$ & $\begin{array}{l}\text { - Public service spending } \\
\text { - Energy efficiency of building and urban morphology }\end{array}$ & $\begin{array}{l}\text { - Energy prices (domestic) } \\
\text { - Attitudes to energy efficiency and } \\
\text { sustainability }\end{array}$ & $\begin{array}{l}\text { - Information in the E[R] report } \\
\text { - General narratives from DRC }\end{array}$ \\
\hline $\begin{array}{l}\text { Attitudes to energy efficiency } \\
\text { and sustainability }\end{array}$ & $\begin{array}{l}\text { - Attitudes to consumerism } \\
\text { - Civic activism }\end{array}$ & -- & - General GSG narratives \\
\hline $\begin{array}{l}\text { Average dwelling (usable) } \\
\text { floor area }\end{array}$ & $\begin{array}{l}\text { - Average household size } \\
\text { - Housing affordability } \\
\text { - Urban dwelling density } \\
\text { - Settlement pattern (city scale) } \\
\text { - Settlement pattern (neighbourhood scale) } \\
\text { - Need for affordable housing }\end{array}$ & - Type of building & - General narratives from DRC. \\
\hline $\begin{array}{l}\text { Average number and } \\
\text { frequency of use of electric } \\
\text { appliances }\end{array}$ & $\begin{array}{l}\text { - Average household size } \\
\text { - Attitudes to consumerism } \\
\text { - Income inequality }\end{array}$ & $\begin{array}{l}\text { - Attitudes to energy efficiency and } \\
\text { sustainability }\end{array}$ & - Information in the Technical document \\
\hline Dwelling area per occupant & $\begin{array}{l}\text { - Average household size } \\
\text { - Household overcrowding }\end{array}$ & $\begin{array}{l}\text { - Average dwelling (usable) floor } \\
\text { area }\end{array}$ & -- \\
\hline Energy poverty & $\begin{array}{l}\text { - Energy efficiency of building and urban morphology } \\
\text { - Income } \\
\text { - Income inequality } \\
\text { - Public service spending } \\
\text { - Community cohesion } \\
\end{array}$ & $\begin{array}{l}\text { - Energy prices (domestic) } \\
\text { - Adoption of domestic (or } \\
\text { community) microgeneration }\end{array}$ & -- \\
\hline Energy prices (domestic) & -- & -- & $\begin{array}{l}\text { - Information in the E[R] report } \\
\text { - Information in the Technical document } \\
\text { - Table generation tool }\end{array}$ \\
\hline Type of building & $\begin{array}{l}\text { - Adaptability of buildings and supporting } \\
\text { infrastructure to new use } \\
\text { - Settlement pattern (city scale) } \\
\text { - Settlement pattern (neighbourhood scale) } \\
\text { - Urban dwelling density } \\
\text { - Total amount of green space } \\
\text { - Urbanization } \\
\text { - Land use } \\
\text { - Planning policy } \\
\text { Planning adherence }\end{array}$ & -- & - General narratives from DRC \\
\hline
\end{tabular}




\begin{tabular}{|l|l|l|l|}
\hline $\begin{array}{l}\text { Use of electric space (and } \\
\text { water) heating }\end{array}$ & -- & $\begin{array}{l}\text { Adoption of domestic (or } \\
\text { community) microgeneration } \\
\text { A Attitudes to energy efficiency and } \\
\text { sustainability } \\
\text { - Energy prices (domestic) }\end{array}$ & $\bullet$ Information in E[R] \\
\hline
\end{tabular}

\section{Characteristics 1}

\section{Characteristics 2}

.

:

Characteristics $\mathrm{n}$

\section{$\oplus$ Other information}

\section{New characteristics}




\subsection{Indicator 'Energy prices (domestic)'}

289

290 The previous method was not used to develop the indicator 'Energy prices (domestic)', as there are 291 many factors which influence these prices and most of these factors are not related to the indicators

292 from DRC. Based on the fact that the GSG used previous versions of the Energy [R]evolution report 293 (Greenpeace/EREC, 2007, 2008) to develop the energy-related information of their scenarios, the basis 294 to develop the characteristics of this indicator was the information about future energy prices from the 295 latest Energy [R]evolution report (Greenpeace, 2015). See Appendix A7 for details.

\section{Results}

299

300 The results of this work are presented here in table form (Table 2). The table shows the indicators 301 developed, their metrics and baselines. Next to them, for each scenario it shows their global tendency 302 in relation to the baseline (by means of an arrow) and their characteristics. The scenarios are: New 303 Sustainability Paradigm (NSP), Policy Reform (PR), Market Forces (MF), and Fortress World (FW).

305 Part of the results which give context to this table can be found in the Appendix. There, the following

306 information is provided for each indicator: a justification or definition, the question it answers, an extended version of the baseline*, and a short description of its context for each scenario (Table A1 -

308 Review and context) $)^{*}$. It is recommended to have the Appendix at hand when using the results table. 
313 Table 2. Indicators table: characteristics of each of the new indicators for each scenario.

\begin{tabular}{|c|c|c|c|c|c|c|}
\hline \multirow{2}{*}{ Indicator } & \multirow{2}{*}{ Metric } & \multirow{2}{*}{ Baseline } & \multicolumn{4}{|c|}{ Characteristics } \\
\hline & & & UK urban NSP & UK urban PR & UK urban MF & UK urban FW (rich | poor) \\
\hline 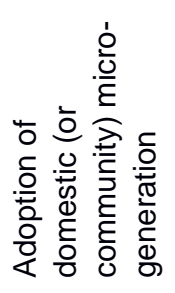 & $\begin{array}{l}\text { \% of } \\
\text { domestic } \\
\text { energy } \\
\text { consumpti } \\
\text { on met } \\
\text { with micro- } \\
\text { generation }\end{array}$ & $\begin{array}{l}1.3 \% \\
\text { domestic } \\
(2016) \text { and } \\
\sim 0.1 \% \\
\text { community } \\
\text { (2017) }\end{array}$ & $\begin{array}{l}\quad \Uparrow \\
\text { Most domestic energy } \\
\text { consumption is met with } \\
\text { microgeneration, mainly at } \\
\text { community level. }\end{array}$ & $\begin{array}{l}\quad \Uparrow \\
\text { A large percentage of } \\
\text { domestic energy } \\
\text { consumption is met with on- } \\
\text { site or community } \\
\text { microgeneration. }\end{array}$ & $\begin{array}{l}\text { On-site microgeneration } \\
\text { increases but the percentage } \\
\text { of domestic energy met by it } \\
\text { is not very large. }\end{array}$ & $\begin{array}{l}\qquad \Uparrow \mid \Downarrow \\
\text { The overall adoption of } \\
\text { microgeneration and the } \\
\text { percentage of domestic } \\
\text { energy met by it are slightly } \\
\text { higher than current. }\end{array}$ \\
\hline 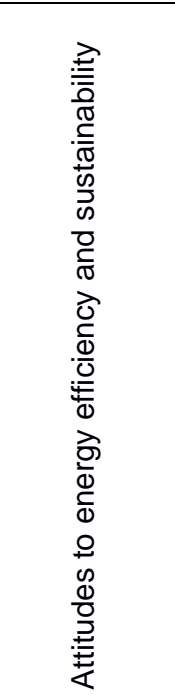 & $\mathrm{N} / \mathrm{A}$ & $\begin{array}{l}\text { some good } \\
\text { intentions, } \\
\text { less results }\end{array}$ & $\begin{array}{l}\text { ल } \\
\text { People have the will to be } \\
\text { sustainable, the information } \\
\text { to be so is widely available, } \\
\text { and rules and society favour } \\
\text { it. The result is a very } \\
\text { sustainable society with } \\
\text { people willing and able to be } \\
\text { sustainable. }\end{array}$ & $\begin{array}{l}\text { People's mindset does not } \\
\text { change substantially from the } \\
\text { current. However, the } \\
\text { government puts a lot of } \\
\text { effort in sustainable } \\
\text { measures to make } \\
\text { sustainability the default } \\
\text { option. Information is reliable } \\
\text { and available, making it } \\
\text { easier to act sustainably. The } \\
\text { result is a society which is } \\
\text { more sustainable than } \\
\text { currently (but far less than in } \\
\text { NSP), especially the } \\
\text { individuals who are engaged. }\end{array}$ & 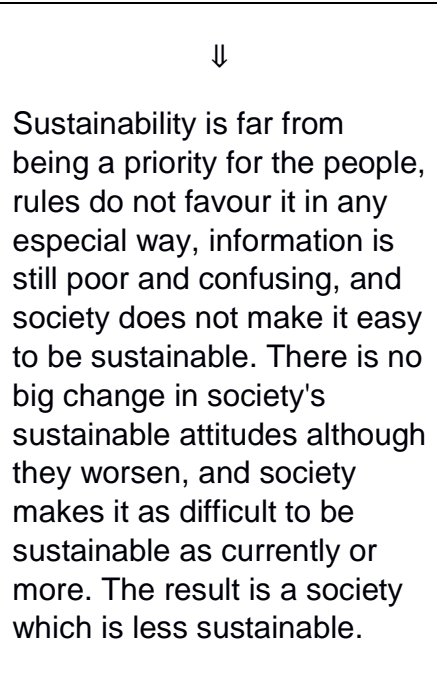 & $\begin{array}{l}\qquad \Downarrow \mid \Downarrow \\
\text { Rich: governments try to } \\
\text { keep up with sustainability } \\
\text { measures but their priority is } \\
\text { security. People, locked up in } \\
\text { their enclaves, are not —or } \\
\text { do not want to be- aware of } \\
\text { the rest of the world. Their } \\
\text { attitudes to sustainability are } \\
\text { almost inexistent. } \\
\text { Poor: although some - } \\
\text { especially the youth-grow } \\
\text { expectations of fairness and } \\
\text { may dream of sustainability, } \\
\text { they have many much more } \\
\text { urgent issues to deal with. }\end{array}$ \\
\hline
\end{tabular}




\begin{tabular}{|c|c|c|c|c|c|c|}
\hline 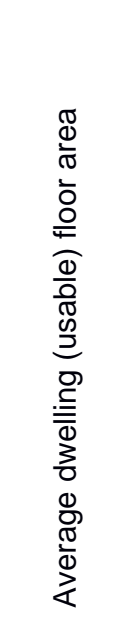 & $\begin{array}{l}\text { average } \\
\text { usable } \\
\text { floor area } \\
\text { in } \mathrm{m}^{2}\end{array}$ & $\begin{array}{l}\text { mean total } \\
\text { usable } \\
\text { floor area } \\
\text { of } 95 \mathrm{~m}^{2} \\
(2013)\end{array}$ & $\begin{array}{l}\Leftrightarrow \\
\text { Although people tend to live } \\
\text { together in larger households } \\
\text { than currently, the average } \\
\text { dwelling usable floor area } \\
\text { decreases only slightly. This } \\
\text { is mainly due to the increased } \\
\text { use of flats rather than } \\
\text { houses and is exacerbated } \\
\text { by the co-housing movement. }\end{array}$ & $\begin{array}{l}\Downarrow \\
\text { As household size decreases } \\
\text { and there is an increase in } \\
\text { typically smaller dwellings } \\
\text { (flats), the average dwelling } \\
\text { floor area decreases notably. }\end{array}$ & $\begin{array}{l}\qquad \Downarrow \\
\text { The average dwelling floor } \\
\text { area decreases. The main } \\
\text { effect is, however, the } \\
\text { polarisation: with a strong } \\
\text { increase in dwellings with } \\
\text { less than } 50 \mathrm{~m}^{2} \text { of internal } \\
\text { floor space, and also an } \\
\text { increase in those with more } \\
\text { than } 110 \mathrm{~m}^{2} \text {. }\end{array}$ & $\begin{array}{l}\text { त| } \Downarrow \\
\text { Rich: the average dwelling } \\
\text { floor area for the rich is much } \\
\text { higher than the current }(110 \\
\mathrm{m}^{2} \text { being close to their lower } \\
\text { end). } \\
\text { Poor: the average dwelling } \\
\text { floor area for the poor is } \\
\text { much lower than the current. } \\
\text { Most of those with dwellings } \\
\text { larger than } 50 \mathrm{~m}^{2} \text { share their } \\
\text { dwelling and many cannot } \\
\text { even afford to live in formal } \\
\text { developments. }\end{array}$ \\
\hline 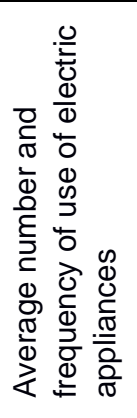 & $\mathrm{N} / \mathrm{A}$ & $\begin{array}{l}\text { almost } \\
\text { ubiquitous } \\
\text { presence } \\
\text { of washing } \\
\text { machines, } \\
\text { refrigeratio } \\
\mathrm{n} \text { and } \\
\text { media } \\
\text { appliances } \\
\text { (2011) }\end{array}$ & $\begin{array}{l}\Downarrow \\
\text { People tend to have and use } \\
\text { appliances less than today. }\end{array}$ & $\begin{array}{l}\text { Appliance use and ownership } \\
\text { is similar to current, only } \\
\text { slightly higher due to smaller } \\
\text { households. }\end{array}$ & $\begin{array}{l}\text { Dwellings have a larger } \\
\text { number of appliances and } \\
\text { they are more intensively } \\
\text { used than today. }\end{array}$ & $\begin{array}{l}\qquad \Uparrow \mid \Downarrow \\
\text { Overall there are less } \\
\text { appliances and are less used } \\
\text { because of the large weight } \\
\text { of the poor population } \\
(35: 65) \text {. }\end{array}$ \\
\hline 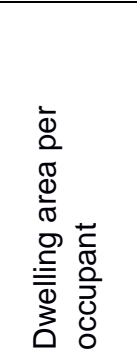 & $\mathrm{m}^{2} /$ person & $\begin{array}{l}\text { one } \\
\text { occupant } \\
\text { every } 41.3 \\
\mathrm{~m}^{2}(2011- \\
13)\end{array}$ & $\begin{array}{l}\qquad \\
\text { The dwelling area per } \\
\text { occupant decreases } \\
\text { considerably out of choice } \\
\text { (very homogeneously, there } \\
\text { is almost no overcrowding). }\end{array}$ & $\begin{array}{l}\qquad \Downarrow \\
\text { The area per occupant } \\
\text { decreases moderately and } \\
\text { homogenously, not by } \\
\text { personal choice but due to } \\
\text { regulations (e.g. favouring } \\
\text { flats over houses, which tend } \\
\text { to be smaller). }\end{array}$ & $\begin{array}{l}\text { त } \\
\text { The average area per } \\
\text { occupant increases to some } \\
\text { extent. However, the main } \\
\text { contributors are middle to } \\
\text { higher classes, as for a part } \\
\text { of the lower classes it may } \\
\text { decrease. }\end{array}$ & $\begin{array}{l}\qquad \Uparrow \mid \Downarrow \\
\text { Rich: increase greatly their } \\
\text { area per occupant. } \\
\text { Poor: decrease greatly their } \\
\text { area per occupant. }\end{array}$ \\
\hline
\end{tabular}




\begin{tabular}{|c|c|c|c|c|c|c|}
\hline 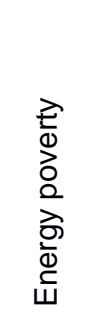 & $\begin{array}{l}\% \text { of } \\
\text { population } \\
\text { in energy } \\
\text { poverty }\end{array}$ & $\begin{array}{l}\text { around } \\
11.0 \% \\
\text { (approxima } \\
\text { tely } 2.50 \\
\text { million } \\
\text { household } \\
\text { s) (2015) }\end{array}$ & $\begin{array}{l}\qquad \\
\text { Better housing, the almost } \\
\text { inexistence of poor people, } \\
\text { and government's and } \\
\text { society's engagement reduce } \\
\text { energy poverty to almost } \\
\text { zero. }\end{array}$ & $\begin{array}{l}\qquad \\
\text { The decrease in poor people, } \\
\text { better housing and the } \\
\text { engagement of the } \\
\text { governments contribute to a } \\
\text { strong decrease in energy } \\
\text { poverty. }\end{array}$ & $\begin{array}{l}\qquad \Leftrightarrow \\
\text { Although inequality increases } \\
\text { substantially, the high } \\
\text { increase in GDP is able to } \\
\text { keep energy poverty similar } \\
\text { to current. }\end{array}$ & $\begin{array}{l}\qquad \| \mid \Uparrow \\
\text { No energy poverty among the } \\
\text { rich. Almost all within the } \\
\text { poor are energy poor. }\end{array}$ \\
\hline 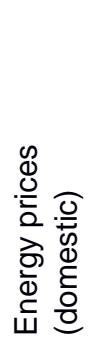 & $\begin{array}{l}\mathrm{p} \text { (penny } \\
\text { sterling)/k } \\
\text { Wh }\end{array}$ & $\begin{array}{l}\text { Electricity } \\
\text { (e): } 15.47 \\
\mathrm{p} / \mathrm{kWh} \\
(2016) ; \\
\text { Gas }(\mathrm{g}): \\
4.31 \mathrm{p} / \mathrm{kWh} \\
(2016)\end{array}$ & $\begin{array}{l}\qquad \mathrm{e} \Uparrow \mathrm{g} \Downarrow \\
\text { Electricity price will increase } \\
\text { similarly to that in MF } \\
\text { (17.36p/kWh). } \\
\text { The gas price will decrease } \\
\text { further than in PR (3.54 } \\
\mathrm{p} / \mathrm{kWh).}\end{array}$ & $\begin{array}{l}\quad \mathrm{e} \Leftrightarrow \mathrm{g} \Downarrow \\
\text { Electricity price will be very } \\
\text { similar to current, } \\
15.25+\mathrm{p} / \mathrm{kWh} \text {. } \\
\text { Gas price will steadily } \\
\text { decrease until } 3.54 \mathrm{p} / \mathrm{kWh} \text {. }\end{array}$ & $\begin{array}{l}\qquad \mathrm{e} \Uparrow \mathrm{g} \Uparrow \\
\text { Electricity price will increase } \\
\text { almost steadily until } \\
17.36++\mathrm{p} / \mathrm{kWh} \text {. } \\
\text { Gas price will steadily } \\
\text { increase until } 6.21 \mathrm{p} / \mathrm{kWh} \text {. }\end{array}$ & $\begin{array}{l}\quad \mathrm{e} \Uparrow \mathrm{g} \Uparrow \\
\text { Electricity price will increase } \\
\text { even further than in MF } \\
\text { (17.36+++ } \mathrm{p} / \mathrm{kWh}) \text {. } \\
\text { Gas price will increase but } \\
\text { less than in MF }(6.21 \text { - } \\
\mathrm{p} / \mathrm{kWh}) \text {. }\end{array}$ \\
\hline 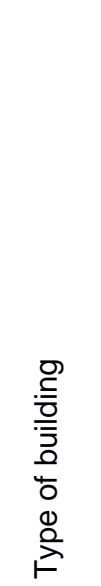 & $\begin{array}{l}\% \text { of the } \\
\text { building } \\
\text { stock } \\
\text { compared } \\
\text { to baseline }\end{array}$ & $\begin{array}{l}\text { End } \\
\text { terrace } \\
10.4 \% \text {, } \\
\text { mid terrace } \\
18.8 \% \text {, } \\
\text { semidetac } \\
\text { hed } 27.6 \\
\% \text {, } \\
\text { detached } \\
22.6 \% \text {, flat } \\
20.6 \% \\
(2013)\end{array}$ & $\begin{array}{l}\text { Flats: increase. } \\
\text { Terraced: similar with } \\
\text { tendency to decrease. } \\
\text { (Semi-) detached: decrease. }\end{array}$ & $\begin{array}{l}\text { Flats: increase. } \\
\text { Terraced: slight increase. } \\
\text { (Semi-) detached: decrease } \\
\text { (especially semi-detached, as } \\
\text { people who can afford it } \\
\text { prefer to pay more (detached) } \\
\text { for increased privacy). }\end{array}$ & $\begin{array}{l}\text { Flats: increase. } \\
\text { Terraced: moderate } \\
\text { decrease. } \\
\text { (Semi-) detached: increase. }\end{array}$ & $\begin{array}{l}\text { Rich: } \\
\text { Flats: strong decrease. } \\
\text { Terraced: slight increase. } \\
\text { (Semi-) detached: strong } \\
\text { increase. } \\
\text { Poor: } \\
\text { Flats: stay the same } \\
\text { percentage. } \\
\text { Terraced: decrease. } \\
\text { (Semi-) detached: strong } \\
\text { decrease. } \\
\text { Appearance of large informal } \\
\text { developments with shacks } \\
\text { and tent-like dwellings. }\end{array}$ \\
\hline
\end{tabular}




\begin{tabular}{|c|c|c|c|c|c|c|}
\hline 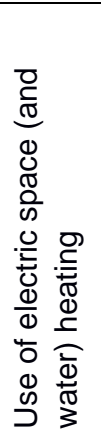 & $\begin{array}{l}\% \text { of } \\
\text { household } \\
\text { s using } \\
\text { electric } \\
\text { heating }\end{array}$ & $\begin{array}{l}8.5 \% \\
(2.2 \mathrm{~m} \\
\text { household } \\
\text { s) }(2015)\end{array}$ & $\begin{array}{l}\text { तhere is a moderate increase } \\
\text { in use of electric space } \\
\text { heating. }\end{array}$ & $\begin{array}{l}\text { There is an important growth } \\
\text { in the use of electric space } \\
\text { heating, mainly incentivised } \\
\text { by the government. Probably } \\
\text { the increase is slightly } \\
\text { smaller in electric water } \\
\text { heating as technologies as } \\
\text { solar thermal are normally not } \\
\text { used for space heating. }\end{array}$ & $\begin{array}{l}\text { There is a slow increase in } \\
\text { the use of electric space and } \\
\text { water heating systems. }\end{array}$ & $\begin{array}{l}\qquad \mid \Downarrow \\
\text { The general trend is a slight } \\
\text { decrease in the use of } \\
\text { electric space and water } \\
\text { heating systems. However, it } \\
\text { increases within the rich. }\end{array}$ \\
\hline
\end{tabular}




\section{Case study}

318

319 To demonstrate the utility of the indicators and characteristics developed in this work, DRC is used with

320 the additions presented here to evaluate the resilience of one of the recommendations of the Swedish

321 measurement campaign mentioned in the introduction (Zimmermann, 2009): the implementation of a

322 ban to appliances with standby power above $0.5 \mathrm{~W}$.

323

324 The UF methodology consists of 4 steps: 1) identify a solution-benefit pair, 2) identify the necessary

325 conditions, 3) determine the performance of necessary conditions in each scenario, and 4) determine

326 the resilience of the pair in the future. With this information one can decide whether to implement the

327 solution or not. For more details about the UF methodology see Lombardi et al., (2012) or Rogers et 328 al., (2012).

329

330 The benefit of the solution chosen is to decrease the electricity consumed in households. Therefore,

331 the solution-benefit pair is: 'implementation of a ban on appliances with standby power above 0.5 W''decrease the electricity consumed in households'.

333

334 The identified necessary conditions for this solution-benefit pair to work are:

1. Appliances must be used

2. Users must use standby mode

3. Governments must be able to enforce the ban

340 Table 3 shows the summary of the futures analysis for the necessary conditions above. The 341 characteristics of 'Average number and frequency of use of electric appliances' directly determine the performance of condition 1. To determine the performance of condition 2, the characteristics of several

343 indicators are needed, with 'Attitudes to energy efficiency and sustainability' and 'Energy price 344 (domestic)' being central. For the other two necessary conditions, the existing DRC covers their 345 analysis. Therefore, without the additions presented in this paper, a user choosing to evaluate the resilience of such a benefit-solution pair would need to infer ad hoc the information used to evaluate 
348 the relevant information, and this would likely cause the result to be less consistent.

350 Table 3. Summary of the futures analysis of the conditions needed for the pair 'implementation of a ban to appliances with standby power above 0.5 W'-'decrease the electricity consumed in households' $(\checkmark$, supported in the scenario; ?, questionable if supported in the scenario; $X$, not supported in the scenario).

\begin{tabular}{|l|l|l|l|l|}
\hline \multirow{2}{*}{ Condition } & \multicolumn{4}{l|}{ Performance } \\
\cline { 2 - 6 } & NSP & PR & MF & $\begin{array}{l}\text { FW } \\
\text { (rich|poor) }\end{array}$ \\
\hline Appliances must be used & $\checkmark$ & $\checkmark$ & $\checkmark$ & $\checkmark \mid \times$ \\
\hline Users use standby mode & $?$ & $\checkmark$ & $\checkmark$ & $\checkmark \mid \times$ \\
\hline Governments must be able to enforce the ban & $\checkmark$ & $\checkmark$ & $?$ & $?$ \\
\hline Policy is maintained despite changes in government & $\checkmark$ & $\checkmark$ & $?$ & $?$ \\
\hline
\end{tabular}

The results of the analysis recommend implementing the solution because it delivers benefits in all scenarios. Its weak points are in MF and FW, where pressure from users (MF) and/or from producers (MF and FW) could lead the government to either withdrawal the measure or be lax in its application; and in FW where it is not useful for the poor. However, the application of the measure obliges producers to develop low consuming standby modes which are appealing to users. Only if producers do not manage to do it, or the implementation of these standby modes continues to be expensive for the producers will these benefits be jeopardised. See Table 4 for a synthesis of the results for each scenario.

Table 4. Synthesis of the results of the futures analysis of the solution-benefit pair 'implementation of a ban to appliances with standby power above 0.5 W'-'decrease the electricity consumed in households'.

\begin{tabular}{|c|c|c|c|}
\hline NSP & PR & MF & FW \\
\hline $\begin{array}{l}\text { The solution delivers } \\
\text { its intended benefits. It } \\
\text { does so less than in PR } \\
\text { because it is less } \\
\text { needed: fewer } \\
\text { appliances are used } \\
\text { and they are often fully } \\
\text { stopped instead of left } \\
\text { in standby mode. }\end{array}$ & $\begin{array}{l}\text { All conditions perform } \\
\text { well. In this scenario, } \\
\text { the solution is useful } \\
\text { and needed. }\end{array}$ & $\begin{array}{l}\text { This is a very useful } \\
\text { and needed solution in } \\
\text { this scenario. } \\
\text { However, it is possible } \\
\text { that it is withdrawn due } \\
\text { to market pressures } \\
\text { (from users or } \\
\text { producers), or not fully } \\
\text { enforced. }\end{array}$ & $\begin{array}{l}\text { This is a useful and } \\
\text { needed solution for the } \\
\text { rich only, as the poor } \\
\text { barely use appliances } \\
\text { and turn them off when } \\
\text { not in use. Although } \\
\text { the government is } \\
\text { more keen than in MF } \\
\text { in securing resources, } \\
\text { they may make } \\
\text { exceptions when faced } \\
\text { with large companies. }\end{array}$ \\
\hline
\end{tabular}


371 It is important to apply futures analysis to sustainable interventions of all kinds to evaluate their resilience and decrease by design the possibility that assets grow stranded while still operative.

373 Broadening the possible uses of scenario analysis to specific domains, as done in this work, may help 374 in this regard.

375

376 This work shows how, indeed, the scenarios from 'Designing Resilient Cities' (DRC) can be 377 complemented and adapted to the specific needs of the user. Figure 3 portrays it graphically: some factors affecting the energy demand in households were not characterised in DRC; they have now been characterised and complement the tool. The scenarios adapted here have a structure - a general narrative plus the characteristics of a set of indicators (Figure 1) - very similar to that of a large body of scenarios developed in the literature. Therefore, this work demonstrates also how such types of scenarios could be adapted to study specific domains of interest outside the original scope of the scenario.

As the case study shows, the generation of the new indicators presented here allows the systematic evaluation of interventions aimed at decreasing the energy consumed in households. This demonstrates the power of future scenarios and their possible extensions to help reveal where alternative thinking may help policy and practice. The specific extension presented here also allows, for example, to explore the evolution of different aspects related to the household energy demand in the different future scenarios, or to project into them current household energy demand data to study their evolution. These properties can be used to inform better regulations or interventions related to the built environment or to plan better, more resilient, energy networks to supply dwellings.

394 This paper further supports the evidence from the extensive literature regarding future scenarios, in that 395 these are powerful tools to help thinking about the future. In addition, not only does it convey the additional tables of characteristics for each scenario to aid that thinking; it also trains the readers in the process of future thinking and scenario building so that they can form their own arguments. The readers, therefore, are able to use future scenarios and also to develop them further if necessary. 


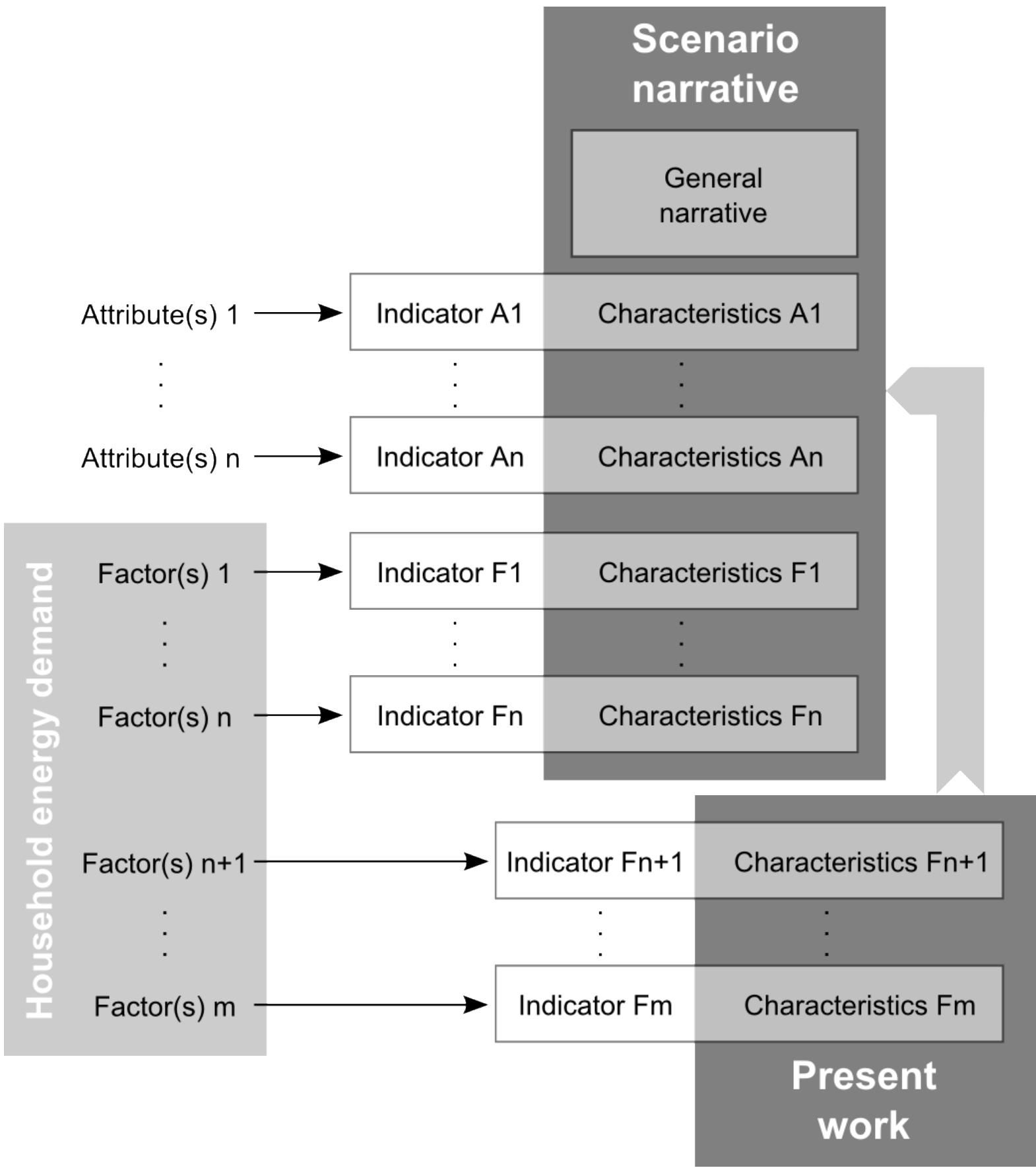

401 Figure 3. Graphical description of the work done for this paper and how it complements the scenarios 402 from DRC. Some of the attributes represented by the indicators from DRC are factors affecting the 403 energy demand of households. The work done here has defined indicators to represent the missing 404 factors affecting the energy demand of households and characterised them to complement the 405 scenarios from DRC. 
409 In order for any intervention not to lose its effectiveness in the future, it is important to make sure it is 410 resilient regardless how the future evolves. Future scenarios are a good tool for helping to designing 411 such resilient interventions. In particular, buildings are responsible for a significant proportion of the 412 greenhouse gas emissions and their average lifespans are very long. It is, therefore, crucial for any 413 intervention in the built environment to deliver its desired effects irrespective of the future which arises.

414 In addition, future scenarios can as well reveal where alternative thinking may help to improve policy 415 for a changing future.

416

417 The factors affecting the energy demand in households are complex and interrelated. However, it is 418 possible to curate a set of indicators to take them into account and characterise their evolution in a 419 range of distinct futures.

420

421 A set of indicators were characterised to adapt the tool 'Designing Resilient Cities' (DRC) to the study of the energy demand in the residential sector. As shown with the case study, this set of indicators can

423 be successfully used, together with $\mathrm{DRC}$, to evaluate the resilience of interventions aimed at decreasing the energy demand in households. This can be used to improve the design of any kind of intervention in this domain, i.e. policy related to housing or interventions aimed at decreasing the energy demand in households.

427

428 This paper has demonstrated the methods used to expand existing future scenarios. In doing so, it 429 trains the readers in future thinking, which they can then use in other domains.

430

431 As future work, DRC could be extended to other specific domains of the urban environment. It could also be adapted to other urban environments or to take climate change into account. 
435 Appendix

436 A Derivation of indicators

437 A1 Adoption of domestic (or community) microgeneration

438

439 Definition/Justification: Microgeneration partly avoids the need to demand energy.

441 Question: What's the percentage of domestic energy consumption met by microgeneration?

442 Baseline UK: in 2016, consumption of self-produced electricity by the domestic sector was 1356 GWh, 443 which accounts for $1.3 \%$ of all domestic consumption (BEIS, 2012), with a total capacity of 2.55 GW 444 (Ofgem, 2017). Total capacity of community installations was about 0.23 GW (Ofgem, 2017), 445 accounting for $\sim 0.1 \%$ of consumption. In 2010 total installed microgeneration capacity (including 446 commercial and industrial) in UK was almost zero.

447 Review and context: See Table A1.

448

449

450

A2 Attitudes to energy efficiency and sustainability

451

452 Justification/definition: This indicator does not measure intentions but results; therefore, it includes education as well as personal preferences, habits and social trends. Intentions do not always match

454 results; partly due to lack of knowledge, difficulty to change habits (Huebner, Cooper and Jones, 2013;

455 Huebner et al., 2015b), or social environment making it difficult.

456

457 Question: What are the general attitudes, knowledge and ease to act in a sustainable way of the 458 population?

459 Baseline UK (2018): Lack of sustainable alternatives and of simple, coherent and relevant information 460 (The Guardian, 2010; Nuttall and Shankar, 2017). A small proportion of population actively tries to 461 reduce their energy consumption and to be more sustainable in general, but lack of reliable information, 462 difficulty to do what is needed in the current society, consumerism, and social inertia makes it very effort 463 intensive. Therefore, many people tend to pick one 'cause' (e. g. avoidance of plastics or veganism) 464 and put most of their efforts there, more than to follow an overall 'sustainable life'. Besides, despite 
good intentions, results are usually very poor due to misinformation, difficulty to change habits and social inertia. And for those who are most knowledgeable, the tension between what they know they should do and what they can actually do can even lead to paralysis (Longo, Shankar and Nuttall, 2017). Saving energy is an idea not promoted beyond it being for saving money (Thøgersen, Curtis and Smith, 2012), therefore it is not high in the sustainability 'causes' list.

470

471

472

\section{A3 Average dwelling (usable) floor area}

473

474 Justification/definition: Larger dwellings tend to consume more energy (Wright, 2008). Also, together with 'Average household size' it gives information on the average number of occupants per usable area dwellings have, which relates to the amount of energy used in dwellings (see Appendix A5).

477

478

Question: How much floor area do dwellings have in comparison to the baseline?

Baseline UK (2013): mean total usable floor area of $95 \mathrm{~m}^{2} ; 9.4 \%$ have less than $50 \mathrm{~m}^{2}$ of internal floor space, $24.9 \%$ have at least $110 \mathrm{~m}^{2}$ of internal floor space (Department for Communities and Local Government, 2015) (Number of dwellings in UK (2013): 23.3 million).

Review and context: See Table A1.

\section{A4 Average number and frequency of use of electric appliances}

486

487 Justification and/or definition: "Electrical appliances make a very significant contribution to a household's electricity consumption. This impact not only relates to the number of each type of

489 appliance owned, but also to the power demand and frequency of use." (Jones, Fuertes and Lomas, 490 2015)

491

492 Question: How is the use of household appliances in the scenario?

493 Baseline UK (2011): from Hulme et al. (2013): 
494 - Laundry appliances: washing machines in $97 \%$ of households. Median use $4 x$ week at $40 \stackrel{\circ}{\mathrm{C}}$ or 495 less. Tumble dryers in $67 \%$ of households. Median use $3 x$ week in winter, few use them in summer.

496 - Refrigeration appliances: refrigerators in $99 \%$ of households (can be combined with freezer).

$497 \quad$ Freezers in $93 \%$ of households.

498 - Dishwashers: in $41 \%$ of households. Median use $4 x$ week.

499 - Cooking appliances: around $38 \%$ of households have electric hobs, around $70 \%$ electric oven, 500 and around $80 \%$ microwave. Use is not determined but the survey 'PERIscope 2017' (Bord Bia, 5012018 ) shows how often people cook food from scratch: Once/few times a day (34\%), Few times a 502 week (31\%), Once a week (11\%), Once/few times a month $(7 \%)$, Less often (9\%), Never (9\%) 503 - Information and communication technologies, and home entertainment: Median number of TVs in 504 homes is 2, the most used one runs 5 to 6 hours per day. No concrete data for other appliances, 505 but different sources show an increase in sells (Euromonitor, 2018), and in appliance energy use $506 \quad$ (Palmer and Cooper, 2013) in the last years.

507 Review and context: See Table A1.

508

509

$510 \quad$ A5 Dwelling area per occupant

511

512 Justification and/or definition: it relates to the amount of energy used in dwellings: more density of 513 occupants means less space heating per person and more likelihood of sharing consumer items

514 (Bhattacharjee and Reichard, 2011).

515

516 Question: What's the average area per occupant in dwellings?

517 Baseline UK (2011-13): Average household size (2011): 2.3 (Office for National Statistics, 2013) (the

518 indicator in DRC shows 2.4, which is the value from 2001). Average dwelling (usable) floor area (2013)

$51995 \mathrm{~m}^{2}$. The result is one occupant every $41.3 \mathrm{~m}^{2}$.

520

521

522 
525 Definition: "Fuel poverty in England is measured using the 'Low Income High Costs' indicator, which considers a household to be fuel poor if: 1) they have required fuel costs that are above average (the national median level); 2) were they to spend that amount, they would be left with a residual income below the official poverty line." (BEIS, 2017a)

529

530 Question: What is the percentage of population in energy poverty?

531 Baseline UK (2015): around $11.0 \%$ (approximately 2.50 million households) (BEIS, 2017a). It has been fluctuating less than 2 percentage points since 2003, between more than $10 \%$ and less than $12 \%$. The average fuel poverty gap in 2015 was $£ 353$, which has been slowly decreasing since peaking in 2012 after at least 10 years rising.

535 Review and context: See Table A1.

536

537

A7 Energy prices (domestic)

539

540 Justification: The price of the domestic energy can influence the energy demand of households, 541 especially those with low income (BEIS, 2017a). This effect may be amplified if energy prices and energy consumption are made visible and may be used to decrease peak demand — by changing energy pricing depending on the time of the day (Darby, 2006). It is expected that an increase in energy

544 prices would incentivise adoption of on-site generation (Jager, 2006).

545 A forecast of the future energy prices is outside the scope of this research. However, the relative differences between scenarios and a rough relation to current values is what we can evaluate.

548 Definition: Average UK domestic energy price (incl. taxes) for a medium customer for a given year.

549 Question: What are the average energy prices of domestic energy (electricity and gas) for a given year? 550 Baseline UK (2016): Average for medium consumers, 2016. Electricity price: 15.47 p/kWh (2012: 14.05 551 p/kWh); Gas: 4.31 p/kWh (2012: 4.46 p/kWh). (BEIS, 2018). 
553 The Global Scenarios Group used Greenpeace's 'Energy [R]evolution' reports $(2007,2008)$ to help to 554 generate the energy related data in their scenarios. These reports portray a Reference scenario (Ref)

555 and an Energy [R]evolution scenario (E[R]) which are broadly compatible with Market Forces (MF) and 556 Policy Reform (PR) respectively. In more recent reports, another scenario is added, Advanced Energy 557 [R]evolution scenario $(\mathrm{AE}[\mathrm{R}])$. This scenario is, however, not compatible with any of the other scenarios used in DRC. Reproductions of the figures and tables used to characterise this indicator can be found in section S2 of the Supplementary information document. They belong to three sources: 1) the latest Energy [R]evolution report by Greenpeace, (2015) (figure 6.4.6 and table 5.4; the figure shows the development of the electricity generation costs in Ref, $E[R]$ and $A E[R]$ for OECD Europe, and the table shows the projections for fossil fuel and biomass prices for different parts of the world until 2050), 2) the technical document of the GSG's scenarios (by Electris et al., (2009); figure 3-44, which shows the electricity generation shares in 2050 in MF and PR compared to those in 2005), and 3) the table generator tool by Tellus Institute, (2018) (which shows the values for different Western Europe scenarios of selected indicators in different points in the future).

567 (Greenpeace, 2015), see Figure S2 in the Supplementary information document) proportional to the electricity generation costs and that this proportionality will not change in time. It is also assumed that taxes stay constant. With these assumptions, the relation between the price of UK domestic electricity and the electricity generation costs in 2012 is the same as the relation between the electricity prices and generation costs in 2050 (for the different scenarios). Therefore, Final electricity price in Ref: $17.36 \mathrm{p} / \mathrm{kWh}$ 
583 to go in the opposite direction in spite of the increases in electricity costs which this implies (HM

584 Government, 2013; BEIS, 2017b). The narratives of the scenarios suggest this increase will be higher

585 in Ref/MF (17.36++ p/kWh) than E[R]/PR (15.25+ p/kWh).

586

587

Calculations of final gas prices in Ref and E[R] (based on information given in Table 5.4

588

(Greenpeace, 2015) see Figure S3 in the Supplementary information document)

589

590

The procedure here is similar than that used with the electricity prices: the price for UK domestic gas

591

in 2012 is defined as proportional to the value for Europe in 2012/2013 shown in the table, and with

592

593

Final gas price in $E[R]: 3.54 \mathrm{p} / \mathrm{kWh}$

594

Final price in Ref: $6.21 \mathrm{p} / \mathrm{kWh}$

595

596

Review and context: See Table A1.

597

598

599

\section{A8 Type of building}

600

601 Justification: Although it is expected that in OECD member countries approximately $75 \%$ of 2013

602 building stock will still be standing in 2050 (IEA, 2013) and, that in the case of UK, more than two-thirds

603 of the 2050 housing stock was already built in 2005 (Boardman et al., 2005), the remaining stock will

604 have an impact on both, direct energy consumption (e. $g$. blocks of buildings use less energy than

605 detached houses) (Bhattacharjee and Reichard, 2011; Jones and Lomas, 2015; Jones, Fuertes and

606 Lomas, 2015) and the heat island effect (gardens help mitigate heat island effect, blocks of buildings

607 increase it) (U.S. Environmental Protection Agency, 2008).

608

609 Question: What is the composition of the domestic building stock?

610 Baseline UK (2013): End terrace $10.4 \%$, mid terrace $18.8 \%$, semidetached $27.6 \%$, detached $22.6 \%$,

611 flat $20.6 \%$ (Department for Communities and Local Government, 2015). For new built: end terrace 10.3 
$612 \%$, mid terrace $12.9 \%$, semidetached $11.0 \%$, detached $23.7 \%$, flat $42.2 \%$ (Department for

613 Communities and Local Government, 2015).

614 Review and context: See Table A1.

615

616

617 A9 Use of electric space (and water) heating

618

619 Justification and/or definition: Heating (space and water) is the largest slice of UK household energy 620 use (80 \%) (Palmer and Cooper, 2013), therefore the amount of dwellings using electric heating has a 621 huge impact in the electricity network's load. "In almost all cases, households that use electricity for 622 space heating also use electricity for water heating" and "the vast majority of households that use 623 electric water heating also use electricity for space heating" (Ofgem, 2015), therefore it does not make 624 sense to separate space and water heating in two distinct indicators.

625 Currently electric heating is not common in the UK and is more expensive than gas heating. However,

626 it is expected to grow by the popularisation of heat pumps, as they are more efficient than other types

627 of electric heating and still are a minority in UK ("typically, heat pumps can produce from 2.5 to 4 times

628 as much useful heat as the amount of high-grade energy input, with variations due to seasonal 629 performance" (Greenpeace, 2015)). The adoption of microgeneration should also push in this direction 630 in the scenarios where decreasing emissions is valued.

631

632 Question: What's the percentage of households using electric space (and water) heating?

633 Review and context: See Table A1.

634

635

636 
638 Table A1 - Review and context. Short description of the context of the new indicators in each scenario.

\begin{tabular}{|c|c|c|c|c|}
\hline & & Review and cor & & \\
\hline & UK urban NSP & UK urban PR & UK urban MF & UK urban FW \\
\hline 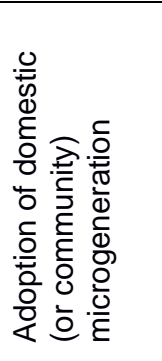 & $\begin{array}{l}\text { Community energy generation units } \\
\text { are widely adopted. There are } \\
\text { polices encouraging } \\
\text { microgeneration, the public has the } \\
\text { willingness and the information to } \\
\text { adopt it, and total energy demand in } \\
\text { households decrease sharply due to } \\
\text { better dwellings and better use by } \\
\text { occupants. }\end{array}$ & $\begin{array}{l}\text { On-site generation is cheap, } \\
\text { electricity is relatively expensive, and } \\
\text { government incentivises clean } \\
\text { energy and promotes community } \\
\text { microgeneration stations. People are } \\
\text { not especially inclined to adopt } \\
\text { microgeneration, but it is profitable, } \\
\text { therefore there is a wide penetration. } \\
\text { Buildings are generally better } \\
\text { insulated. }\end{array}$ & $\begin{array}{l}\text { On site generation is not too cheap, } \\
\text { but high energy prices stimulate the } \\
\text { uptake of domestic microgeneration } \\
\text { by who can afford it. Buildings still } \\
\text { consume a lot of energy, therefore, } \\
\text { although on-site microgeneration } \\
\text { increases, the percentage of } \\
\text { domestic energy met by it is much } \\
\text { less than in NSP and PR. }\end{array}$ & $\begin{array}{l}\text { Rich: high energy prices make it } \\
\text { favourable for them to install } \\
\text { microgeneration devises as in MF. } \\
\text { Poor: they cannot afford individual } \\
\text { microgeneration devises, but in the } \\
\text { cases where communities are in } \\
\text { good terms and not too poor, they } \\
\text { manage to install community energy } \\
\text { generators. }\end{array}$ \\
\hline 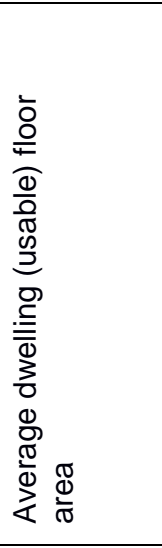 & $\begin{array}{l}\text { There are more people living } \\
\text { together, sometimes as co-housing, } \\
\text { sometimes with friends, extended } \\
\text { family or other families. The dwelling } \\
\text { density increases because although } \\
\text { flat apartments may be slightly larger } \\
\text { than today, they are still smaller than } \\
\text { current average terraced and } \\
\text { detached houses, and many choose } \\
\text { higher quality but smaller homes. } \\
\text { However, the amount of very small } \\
\text { dwellings decreases due to a } \\
\text { decreased interest in living alone and } \\
\text { the almost inexistence of poor } \\
\text { people. }\end{array}$ & $\begin{array}{l}\text { As current individualistic trends } \\
\text { continue, there is a trend toward } \\
\text { smaller household sizes (people do } \\
\text { not want to share accommodation). It } \\
\text { is common to divide large houses in } \\
\text { two to accommodate to the market } \\
\text { and new built tend to be smaller flats } \\
\text { rather than larger houses. }\end{array}$ & $\begin{array}{l}\text { There is a trend towards smaller } \\
\text { household sizes as people do not } \\
\text { want to share accommodation. At the } \\
\text { same time, the affordability of } \\
\text { housing decreases, there is more } \\
\text { substandard housing. There is a high } \\
\text { disparity in urban dwelling density; in } \\
\text { high income zones there is a } \\
\text { prevalence of houses, while in low } \\
\text { income zones there is a prevalence } \\
\text { of flats. }\end{array}$ & $\begin{array}{l}\text { Rich live in a similar way to the } \\
\text { current (or MF) upper } 10 \% \text { or } 15 \% \text {. } \\
\text { A large part of the poor who can } \\
\text { afford to live in formal developments } \\
\text { have to share the dwelling with other } \\
\text { families. Most of those who do not } \\
\text { share their dwelling do so only } \\
\text { because they have been able to } \\
\text { divide it or because the dwelling is } \\
\text { already very small. There are plenty } \\
\text { of informal developments. The trends } \\
\text { seen in MF are here exacerbated. }\end{array}$ \\
\hline 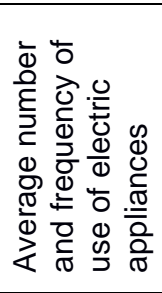 & $\begin{array}{l}\text { Larger households and the will of the } \\
\text { society make sharing home } \\
\text { appliances the norm. More engaged } \\
\text { and sustainable society also has the } \\
\text { effect reducing the superfluous use } \\
\text { and ownership of appliances. }\end{array}$ & $\begin{array}{l}\text { Households tend to be slightly } \\
\text { smaller than today therefore } \\
\text { appliances are shared by less users. } \\
\text { People's search for novelty and } \\
\text { status continues mostly unchanged, } \\
\text { therefore the ownership and use of } \\
\text { appliances increases slightly. }\end{array}$ & $\begin{array}{l}\text { Households are smaller, there is less } \\
\text { interest for sustainability and more } \\
\text { consumerism (the amount of } \\
\text { appliances increases until 2025). } \\
\text { Lower earners may not be able to } \\
\text { afford all the appliances they would } \\
\text { like to have, but this does not } \\
\text { counteract the general trend. }\end{array}$ & $\begin{array}{l}\text { Rich: the situation is similar to that of } \\
\text { the top } 20 \% \text { in MF. } \\
\text { Poor: they cannot afford much. Most } \\
\text { of them have less appliances than } \\
\text { they need - if they can afford to own } \\
\text { some. Sharing, repairing, reusing, } \\
\text { repurposing and recycling appliances } \\
\text { is the norm. }\end{array}$ \\
\hline
\end{tabular}




\begin{tabular}{|c|c|c|c|c|}
\hline 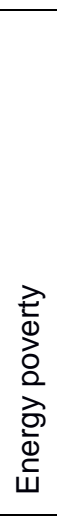 & $\begin{array}{l}\text { Better housing insulation, increase in } \\
\text { GDP per capita, decrease of income } \\
\text { inequality, and increase in public } \\
\text { service spending highly reduce the } \\
\text { risk of energy poverty. Government } \\
\text { helps financing community or on-site } \\
\text { microgeneration if needed. The } \\
\text { extremely few instances of energy } \\
\text { poverty can count on the community } \\
\text { to alleviate their problem. }\end{array}$ & $\begin{array}{l}\text { Better housing insulation and } \\
\text { increase in GDP per capita decrease } \\
\text { energy poverty. The state provides } \\
\text { better insulation, domestic energy } \\
\text { generation and energy tax discounts } \\
\text { if needed. Lower gas prices also help } \\
\text { decrease fuel poverty. }\end{array}$ & $\begin{array}{l}\text { Housing insulation is similar to } \\
\text { current with no better use of sun. } \\
\text { Although GDP increases } \\
\text { substantially, also the gap between } \\
\text { rich and poor increases, leaving a } \\
\text { large portion of society at risk of fuel } \\
\text { poverty. The moderate increase of } \\
\text { energy prices (in comparison with } \\
\text { that of GDP) leave 'only' lowest } \\
\text { earners and those living in especially } \\
\text { badly insulated dwellings in energy } \\
\text { poverty. Government cannot help } \\
\text { mitigate it as it has to spend a lot in } \\
\text { other issues (such as health). }\end{array}$ & $\begin{array}{l}\text { Obviously there are no energy poor } \\
\text { between the rich. The poor, however, } \\
\text { are virtually all energy poor-- } \\
\text { although the definition of energy } \\
\text { poverty partially brakes in this case } \\
\text { as it is difficult to define "required fuel } \\
\text { costs" for those who live in informal } \\
\text { developments. Those who live in } \\
\text { formal developments struggle with } \\
\text { high energy costs and low building } \\
\text { standards. Burning (coal, wood...) is } \\
\text { the main source of heat. }\end{array}$ \\
\hline 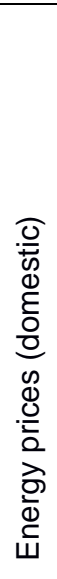 & $\begin{array}{l}\text { In this scenario the general amount } \\
\text { of energy consumed is approximately } \\
\text { one third lower than in PR and it is } \\
\text { mostly in form of electric energy as } \\
\text { well. The share which comes from } \\
\text { renewable sources is only slightly } \\
\text { higher than in PR. This means that } \\
\text { the electricity price will be moderately } \\
\text { higher than in PR as prices will lower } \\
\text { slower (lower increase with same } \\
\text { learning factor implies slower price } \\
\text { reduction). Gas demand is around } 25 \\
\% \text { lower, which will decrease its price } \\
\text { even further. }\end{array}$ & $\begin{array}{l}\text { An increase (peaking in } 2030 \text { at } \\
18.51+\mathrm{p} / \mathrm{kWh} \text { ) and posterior } \\
\text { decrease of the electricity price are } \\
\text { expected. This is due to the } \\
\text { introduction of renewable energy } \\
\text { sources, which are more expensive } \\
\text { at the beginning. However, their price } \\
\text { then decreases rapidly due to the } \\
\text { high learning factor, especially in PV } \\
\text { and CSP. In fact, in } 2050 \text { the energy } \\
\text { from renewable sources is generally } \\
\text { cheaper than that which comes from } \\
\text { fossil fuels (Greenpeace, 2015). } \\
\text { However, lack of demand reduces } \\
\text { gas price. }\end{array}$ & $\begin{array}{l}\text { Increasing prices of fossil fuels (the } \\
\text { more depleted they are, the more } \\
\text { expensive to obtain more it is), low } \\
\text { uptake of renewables (slowing price } \\
\text { reduction due to learning factor) and } \\
\text { increased use of nuclear power, } \\
\text { make electricity prices increase } \\
\text { steadily. The increasing prices of } \\
\text { fossil fuels also affects gas prices. }\end{array}$ & $\begin{array}{l}\text { In this scenario, the general amount } \\
\text { of energy consumed is approximately } \\
10 \% \text { lower than in MF and its } \\
\text { sources are very similar, with a slight } \\
\text { decrease of oil and gas in favour to } \\
\text { coal, nuclear and biomass. In this } \\
\text { case, biomass is not used to } \\
\text { generate electricity; instead it is used } \\
\text { by the poor as a source of heat and } \\
\text { for cooking. The same is probably } \\
\text { true for the increase of coal. The } \\
\text { further increase in nuclear share } \\
\text { affects the electricity price making it } \\
\text { slightly more expensive than in MF. } \\
\text { Gas demand is lower than in MF and } \\
\text { its price is lower too. }\end{array}$ \\
\hline
\end{tabular}




\begin{tabular}{|c|c|c|c|c|}
\hline 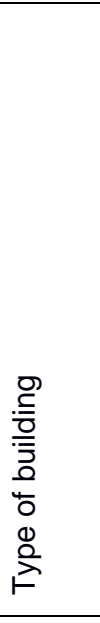 & $\begin{array}{l}\text { There is a decrease in land use, and } \\
\text { an increase in urbanization and in } \\
\text { the amount of green space. This } \\
\text { leads to higher dwelling densities. } \\
\text { There are less dwellings built than in } \\
\text { other scenarios due to high } \\
\text { adaptation of current stock. Current } \\
\text { trends increasing the proportion of } \\
\text { flats are exacerbated, and there are } \\
\text { very few new (semi-) detached } \\
\text { houses constructed. Construction of } \\
\text { terraced houses stays similar. Green } \\
\text { space may be gained where there } \\
\text { were old single-family houses with } \\
\text { garden, especially (semi-) detached } \\
\text { houses. Community feeling drives a } \\
\text { decrease in demand of privacy. }\end{array}$ & $\begin{array}{l}\text { The percentage of new built remains } \\
\text { similar, with a decrease in detached } \\
\text { houses in favour to terraced. This } \\
\text { increases dwelling density due to the } \\
\text { high percentage of new flats } \\
\text { constructed (mainly in city centres) } \\
\text { and lower percentage of (semi-) } \\
\text { detached houses. However, there is } \\
\text { high adaptability of the existing stock, } \\
\text { which decreases the amount of new } \\
\text { built in relation to other scenarios. } \\
\text { Terraced and (semi-) detached } \\
\text { houses are still in high demand as } \\
\text { people seek privacy. }\end{array}$ & $\begin{array}{l}\text { In highly popular and in lower income } \\
\text { neighbourhoods there is a high } \\
\text { increase of flats, while in high income } \\
\text { neighbourhoods what increases is } \\
\text { the presence of new (semi-) } \\
\text { detached houses. This scenario } \\
\text { presents strong "type of building } \\
\text { polarisation". Besides, the } \\
\text { replacement levels are high, } \\
\text { therefore there are more buildings } \\
\text { built than in other scenarios. }\end{array}$ & $\begin{array}{l}\text { There is an overall decrease in } \\
\text { dwelling density, but the polarisation } \\
\text { between rich and poor is extreme in } \\
\text { this scenario. The rich live mainly in } \\
\text { detached and semi-detached } \\
\text { houses, except by in popular zones, } \\
\text { where there is a good provision of } \\
\text { high profile flats too. The poor inhabit } \\
\text { previously built flats and, in some } \\
\text { regions, terraced houses (normally } \\
\text { shared between several families). In } \\
\text { formal developments new flats are } \\
\text { the only new construction. In in- } \\
\text { formal developments dwellings are } \\
\text { more similar to shacks than to proper } \\
\text { buildings. }\end{array}$ \\
\hline 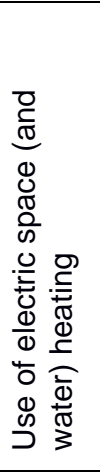 & $\begin{array}{l}\text { Although there is a stronger } \\
\text { decrease in greenhouse gases } \\
\text { produced by household heating than } \\
\text { in PR (and electricity is clean), the } \\
\text { uptake of electric space and water } \\
\text { heating is lower here. The reason is } \\
\text { that there is a much greater increase } \\
\text { of district heating and other forms of } \\
\text { dwelling heating technologies which } \\
\text { use the sun and earth's heat. }\end{array}$ & $\begin{array}{l}\text { Although gas is cheap, as the } \\
\text { government is leading a transition to } \\
\text { clean energy sources, it incentivises } \\
\text { district heating when feasible (often } \\
\text { geothermal) and electric heating } \\
\text { otherwise. The combination of } \\
\text { microgeneration and electric heating } \\
\text { is especially appealing for } \\
\text { customers. Other heating } \\
\text { technologies such as solar thermal } \\
\text { also have their role in order to } \\
\text { replace gas for heating (mostly } \\
\text { water) purposes. }\end{array}$ & $\begin{array}{l}\text { Proportionally, the increase in gas } \\
\text { price is much higher than that of the } \\
\text { electricity. This will increase the } \\
\text { installation of heat pumps in new } \\
\text { built and when systems need to be } \\
\text { changed. Those who have on-site } \\
\text { energy generation will also prefer } \\
\text { electric heating. }\end{array}$ & $\begin{array}{l}\text { Rich: similar to MF but probably } \\
\text { slightly larger as nuclear energy } \\
\text { seem to be preferred than other } \\
\text { sources of energy like gas. } \\
\text { Poor: they are mostly energy poor, } \\
\text { therefore it decreases their use of } \\
\text { electric heating. They mostly use } \\
\text { biomass or coal for heat. }\end{array}$ \\
\hline
\end{tabular}




\section{Acknowledgements}

643 This work was supported by the University of Portsmouth and University Alliance as part of the Doctoral

644 Training Alliance programme. The first author would like to thank his supervisors for their guidance and 645 patience, and the Laboratory for Cavitation and Micro-Erosion (Göttingen) for their patience and the 646 opportunity given to work in academia, without those the investigation for this paper would have never 647 taken place.

648

649

650

651

References

652 BEIS (Department for Business Energy \& Industrial Strategy) (2012) DUKES chapter 5: statistics on electricity from generation through to sales. HM Government. Available at:

654 https://www.gov.uk/government/statistics/electricity-chapter-5-digest-of-united-kingdom-energy655 statistics-dukes.

656 BEIS (Department for Business Energy \& Industrial Strategy) (2017a) Annual fuel poverty statistics report 2017 (2015 Data). HM Government. Available at:

658 https://www.gov.uk/government/collections/fuel-poverty-statistics.

659 BEIS (Department for Business Energy \& Industrial Strategy) (2017b) The Clean Growth Strategy:

660 Leading the way to a low carbon future. HM Government. Available at:

661 https://www.gov.uk/government/publications/clean-growth-strategy.

662 BEIS (Department for Business Energy \& Industrial Strategy) (2018) Quarterly energy prices tables.

663 Annex. HM Government. Available at: https://www.gov.uk/government/statistics/quarterly-energy-

664 prices-march-2018.

665 Bhattacharjee, S. and Reichard, G. (2011) 'Socio-Economic Factors Affecting Individual Household

666 Energy Consumption: A Systematic Review', in ASME 2011 5th International Conference on Energy

667 Sustainability. Washington, pp. 891-901. doi: 10.1115/ES2011-54615.

668 Boardman, B. et al. (2005) 40\% House. Environmental Change Institute, University of Oxford. doi:

669 10.1016/j.tele.2012.02.001.

670 Bord Bia. About how often would you prepare or cook a meal from scratch? (i.e. using raw/fresh/primary ingredients)?, Statista. Available at: 
$672 \mathrm{https} / / / \mathrm{www}$.statista.com/statistics/303153/frequency-of-cooking-meals-from-scratch-trend-great-

673 britain-uk/ (Accessed: 30 October 2018).

674 Boyko, C. et al. (2012) 'Benchmarking sustainability in cities: The role of indicators and future

675 scenarios', Global Environmental Change. Elsevier Ltd, 22(1), pp. 245-254. doi:

676 10.1016/j.gloenvcha.2011.10.004.

677 Cook, J. et al. (2016) 'Consensus on consensus: a synthesis of consensus estimates on human-

678 caused global warming', Environmental Research Letters, 11(4). doi: 10.1088/1748-

$6799326 / 11 / 4 / 048002$.

680 Darby, S. (2006) The effectiveness of feedback on energy consumption, A Review for DEFRA of the

681 Literature on Metering, Billing and direct Displays. doi: 10.4236/ojee.2013.21002.

682 DEFRA (Department for Environment, Food and Rural Affairs) (2008) Climate Change Act 2008. HM

683 Government. Available at: https://www.legislation.gov.uk/ukpga/2008/27/part/1/crossheading/the-

684 target-for-2050.

685 Department for Communities and Local Government (2015) English Housing Survey PROFILE OF

686 ENGLISH HOUSING. HM Government.

687 Department of Energy and Climate Change (2009) The UK Low Carbon Transition Plan: National

688 strategy for climate and energy. HM Government. doi: 10.1007/BF02393883.

689 Electris, C. et al. (2009) 'The Century Ahead: Four Global Scenarios. Technical Documentation'.

690 Available at: http://www.gsg.org/QuantChoices2.html.

691 Euromonitor, Market value of consumer electronics in the United Kingdom (UK) from 2013 to 2018 (in

692 million euros), Statista. Available at: https://www.statista.com/statistics/491307/consumer-electronics-

693 united-kingdom-uk-market-value/ (Accessed: 30 October 2018).

694 Fell, D. and King, G. (2012) Domestic energy use study: to understand why comparable households

695 use different amounts of energy. London: Department for Energy and Climate Change.

696 Firth, S. et al. (2008) 'Identifying trends in the use of domestic appliances from household electricity

697 consumption measurements', Energy and Buildings, 40(5), pp. 926-936. doi:

698 10.1016/j.enbuild.2007.07.005.

699 Foresight Horizon Scanning Centre and Government Office for Science (2009) Scenario Planning,

700 Government office for science. HM Government. Available at:

701 http://webarchive.nationalarchives.gov.uk/20140108140803/www.bis.gov.uk/assets/foresight/docs/hor 
izon-scanning-centre/foresight_scenario_planning.pdf.

703 Gallopin, G. et al. (1997) Branch Points: Global scenarios and human choice, Stockholm Environment 704 Institute.

705 Greenpeace/EREC (European Renewable Energy Council) (2007) Energy [R]evolution - A

706 sustainable world energy outlook. Greenpeace International and European Renewable Energy 707 Council (EREC).

708 Greenpeace/EREC (European Renewable Energy Council) (2008) Energy [R]evolution - A 709 sustainable EU 27 energy outlook. Greenpeace International and European Renewable Energy 710 Council (EREC).

711 Greenpeace (2015) Energy [R]evolution - A sustainable world energy outlook 2015. Available at:

712 https://www.greenpeace.org/archive-international/en/publications/Campaign-reports/Climate-

713 Reports/Energy-Revolution-2015/.

714 GTI (Great Transition Initiative). Available at: https://greattransition.org/ (Accessed: 30 October 2018).

715 Guerra Santin, O., Itard, L. and Visscher, H. (2009) ‘The effect of occupancy and building

716 characteristics on energy use for space and water heating in Dutch residential stock', Energy and

717 Buildings, 41(11), pp. 1223-1232. doi: 10.1016/j.enbuild.2009.07.002.

718 HM Government (2013) Long-term Nuclear Energy Strategy. Available at:

719 https://www.gov.uk/government/publications/long-term-nuclear-energy-strategy.

720 Hong, S. H. et al. (2006) 'The impact of energy efficient refurbishment on the space heating fuel

721 consumption in English dwellings', Energy and Buildings, 38(10), pp. 1171-1181. doi:

722 10.1016/j.enbuild.2006.01.007.

723 Huebner, G. et al. (2015a) 'Explaining domestic energy consumption - The comparative contribution 724 of building factors, socio-demographics, behaviours and attitudes', Applied Energy. Elsevier Ltd, 159, 725 pp. 589-600. doi: 10.1016/j.apenergy.2015.09.028.

726 Huebner, G. et al. (2015b) 'People use the services energy provides - but buildings and technologies 727 determine how much is used', ECEEE summer study proceedings, pp. 967-978. Available at:

728 http://proceedings.eceee.org/visabstrakt.php?event=5\&doc=5-083-15.

729 Huebner, G. et al. (2016) 'Understanding electricity consumption: A comparative contribution of 730 building factors, socio-demographics, appliances, behaviours and attitudes', Applied Energy, 177, pp. 692-702. doi: 10.1016/j.apenergy.2016.04.075. 
Huebner, G., Cooper, J. and Jones, K. (2013) 'Domestic energy consumption - What role do comfort, habit, and knowledge about the heating system play?', Energy and Buildings. Elsevier B.V., 66, pp. 626-636. doi: 10.1016/j.enbuild.2013.07.043.

Hulme, J. et al. (2013) Energy follow-up survey 2011. Report 9: Domestic appliances, cooking \& cooling equipment. BRE.

Hunt, D. et al. (2012a) 'Scenario archetypes: Converging rather than diverging themes', Sustainability, 4(4), pp. 740-772. doi: 10.3390/su4040740.

Hunt, D. et al. (2012b) Urban Futures monograph: Using Scenarios to Explore Urban UK Futures: A review of Futures Literature from 1997 to 2011. Engineering and Physical Sciences Research Council

741 (EPSRC).

742 IEA (International Energy Agency) (2013) Transition to sustainable buildings: Strategies and opportunities to 2050, lea.Org. OECD Publishing. doi: 10.1787/9789264202955-en. IPCC (Intergovernmental Panel on Climate Change) (2000) IPCC special report - Emissions scenarios, Intergovernmental Panel on Climate Change. doi: 92-9169-113-5. Jager, W. (2006) 'Stimulating the diffusion of photovoltaic systems: A behavioural perspective', Energy Policy, 34(14), pp. 1935-1943. doi: 10.1016/j.enpol.2004.12.022. Jones, R. V., Fuertes, A. and Lomas, K. J. (2015) 'The socio-economic, dwelling and appliance related factors affecting electricity consumption in domestic buildings', Renewable and Sustainable Energy Reviews. Elsevier, 43, pp. 901-917. doi: 10.1016/j.rser.2014.11.084. Jones, R. V. and Lomas, K. J. (2015) 'Determinants of high electrical energy demand in UK homes:

752 Socio-economic and dwelling characteristics', Energy and Buildings. Elsevier B.V., 101, pp. 24-34. doi: 10.1016/j.enbuild.2015.04.052.

754 Lombardi, R. et al. (2012) Designing Resilient Cities: a guide to good practice. Bracknell: IHS BRE 755 Press.

756 Longo, C., Shankar, A. and Nuttall, P. (2017) “It's Not Easy Living a Sustainable Lifestyle”: How

757 Greater Knowledge Leads to Dilemmas, Tensions and Paralysis', Journal of Business Ethics.

758 Springer Netherlands, pp. 1-21. doi: 10.1007/s10551-016-3422-1.

Nuttall, P. and Shankar, A. (2017) 'How too much information can stop people from being sustainable

760 consumers', The Conversation. Available at: https://theconversation.com/how-too-much-informationcan-stop-people-from-being-sustainable-consumers-72316. 
762 Office for National Statistics (2013) 2011 Census: Population and household estimates for the United 763 Kingdom. Available at:

764 https://www.ons.gov.uk/peoplepopulationandcommunity/populationandmigration/populationestimates/ 765 bulletins/populationandhouseholdestimatesfortheunitedkingdom/2011-03-21.

766 Ofgem (Office of Gas and Electricity Markets) (2015) Insights paper on households with electric and 767 other non-gas heating. Available at: https://www.ofgem.gov.uk/ofgem-

768 publications/98027/insightspaperonhouseholdswithelectricandothernon-gasheating-pdf.

769 Ofgem (Office of Gas and Electricity Markets) (2017) Feed-in Tariff - Annual Report 2017. Available

770 at: https://www.ofgem.gov.uk/system/files/docs/2017/12/feed-in_tariff_fit_annual_report_2016-

771 17_0.pdf.

772 Palmer, J. and Cooper, I. (2013) United Kingdom housing energy fact file, Department of Energy \& 773 Climate Change. doi: URN: 13D/276.

774 Perry, A. and Bessant, N. (2014) SAVE (Solent Achieving Value from Efficiency) Report 1 - Lessons 775 learnt on Energy Efficiency \& Behavioural Change. London. Available at:

776 https://www.ssen.co.uk/WorkArea/DownloadAsset.aspx?id=7876.

777 Raskin, P. et al. (1998) Bending the Curve : Toward Global Sustainability. Stockholm: Stockholm 778 Environment Institute. Available at: https://www.tellus.org/pub/Bending the Curve - Toward Global 779 Sustainability.pdf.

780 Raskin, P. et al. (2002) Great Transition. The Promise and Lure of the Times Ahead, Stockholm 781 Environment Institute; Global Scenario Group. doi: 10.1016/j.jacr.2010.10.010.

782 Raskin, P., Electris, C. and Rosen, R. (2010) 'The century ahead: Searching for sustainability', 783 Sustainability, 2(8), pp. 2626-2651. doi: 10.3390/su2082626.

784 Rockström, J. et al. (2009) 'Planetary boundaries: exploring the safe operating space for humanity', 785 Ecology and society. JSTOR, 14(2). doi: 10.1007/s13398-014-0173-7.2.

786 Rogers, C. (2012) '[Special issue]', Engineering Sustainability. ICE, 165(1), pp. 1-110. Available at: 787 https://www.icevirtuallibrary.com/toc/jensu/165/1.

788 Rogers, C. et al. (2012) 'The urban futures methodology applied to urban regeneration', Proceedings 789 of the Institution of Civil Engineers - Engineering Sustainability, 165(1), pp. 5-20. doi:

$790 \quad$ 10.1680/ensu.2012.165.1.5.

791 Schwartz, P. (1991) The Art of the Long View: planning for the future in an uncertain world. New York: 
Currency Doubleday.

793 Sonderegger, R. C. (1978) 'Movers and stayers: The resident's contribution to variation across

794 houses in energy consumption for space heating', Energy and Buildings, 1(3), pp. 313-324. doi:

$795 \quad 10.1016 / 0378-7788(78) 90011-7$.

796 Tellus Institute, Data Tables. Available at: https://www.tellus.org/cgi-bin/scenarios/sds.cgi (Accessed:

79730 October 2018).

798 The Guardian (2010) Consumer attitudes and perceptions on sustainability, The Guardian:

799 Sustainable Business. doi: 10.1021/am200647f.

800 Thøgersen, J., Curtis, J. and Smith, L. (2012) 'Simple steps to save the environment may not make

801 much difference', The Conversation. Available at: https://theconversation.com/simple-steps-to-save-

802 the-environment-may-not-make-much-difference-6507.

803 Thomas, R. (2006) Environmental design - An introduction for architects and engineers. Third edit.

804 Taylor and Francis.

805 U.S. Environmental Protection Agency (2008) 'Reducing Urban Heat Islands: Compendium of

806 Strategies Urban Heat Island Basics', in, pp. 1-22. Available at: https://www.epa.gov/heat-

807 islands/heat-island-compendium.

808 Weber, I. et al. (2017) Explaining flat-specific heating energy consumption by building physics and

809 behaviour. An interdisciplinary approach. Available at:

810 https://www.researchgate.net/profile/Ines_Weber3/publication/318395056_Explaining_flat-

811 specific_heating_energy_consumption_by_building_physics_and_behaviour_An_interdisciplinary_ap

812 proach_Explaining_flat-specific_heating_energy_consumption_by_building_phys.

813 Wright, A. (2008) 'What is the relationship between built form and energy use in dwellings?', Energy

814 Policy, 36(12), pp. 4544-4547. doi: 10.1016/j.enpol.2008.09.014.

815 Zimmermann, J. P. (2009) End-use metering campaign in 400 households In Sweden Assessment of

816 the Potential Electricity Savings, Contract. doi: Contract 17-05-2743.

817

818 
819 Figures and tables caption list:

820

821 Figure 1. DRC scenarios narrative composition. The narrative of each scenario comprises a brief 822 general narrative describing the main aspects of the scenario, and the characteristics describing the

823 performance of a set of indicators in the scenario. These indicators are variables representing one or 824 more attributes of the system.

825

826 Figure 2. Analogy between the derivation of the characteristics of a new indicator for one scenario and

827 a sum: the added information given by the characteristics of the relevant indicators and other relevant information "logically produces" the characteristics of the new indicator as result.

829

830 Figure 3. Graphical description of the work done for this paper and how it complements the scenarios

831 from DRC. Some of the attributes represented by the indicators from DRC are factors affecting the energy demand of households. The work done here has defined indicators to represent the missing

833 factors affecting the energy demand of households and characterised them to complement the scenarios from DRC.

835

836

837 Table 1. Indicators and other information used to derive each of the new indicator's characteristics.

838 References: E[R] report (Greenpeace, 2015), General narratives from DRC (Lombardi et al., 2012),

839 General GSG narratives (Hunt et al., 2012b), Technical document (Electris et al., 2009), Table 840 generator tool (Tellus Institute, 2018).

841

842 Table 2. Indicators table: characteristics of each of the new indicators for each scenario.

843

844 Table 3. Summary of the futures analysis of the conditions needed for the pair 'implementation of a ban

845 to appliances with standby power above 0.5 W'-'decrease the electricity consumed in households' $(\checkmark$,

846 supported in the scenario; ?, questionable if supported in the scenario; $\times$, not supported in the 847 scenario). 
849 Table 4. Synthesis of the results of the futures analysis of the solution-benefit pair 'implementation of a 850 ban to appliances with standby power above 0.5 W'-'decrease the electricity consumed in households'. 851

852 Table A1 - Review and context. Short description of the context of each of the new indicators for each 853 scenario.

854

855

856 